\title{
Bird assembly in reforested restinga areas
}

\author{
Erich de Freitas Mariano ${ }^{*} \bullet$, Arnaldo Honorato Vieira-Filhob®, Gustavo Alves Toledo da \\ Costac®, Helder Farias Pereira de Araujod®, Malva Isabel Medina Hernándeze® \\ a Laboratório de Pesquisa em Ensino, Zoologia e Conservação, Universidade Federal de Campina Grande, Patos, 58708-110, \\ Paraíba, Brasil.*efmariano.ufcg@gmail.com \\ b Programa de Pós-Graduação em Ciências Biológicas, Universidade Federal da Paraíba, João Pessoa, 58051-900, Paraíba, Brasil. \\ c Programa de Pós-graduação em Psicobiologia, Universidade Federal do Rio Grande do Norte, Natal, 59.078-970, Rio Grande do \\ Norte, Brasil. \\ d Programa de Pós-Graduação em Ecologia, Universidade Federal de Santa Catarina, 88040-900, Santa Catarina, Brasil. \\ e Programa de Pós-Graduação em Ciências Biológicas, Universidade Federal da Paraíba, Areia, , 58397-000, Paraíba, Brasil.
}

Received: December 3, 2020 / Accepted: March 17, 2020 / Published online: May 25, 2020

\begin{abstract}
Landscape fragmentation is among the causes of environmental degradation and biodiversity reduction, mainly in Atlantic Forest areas. This study evaluates differences in avifauna richness and analyzes the structure of functional groups in a native restinga forest fragment (Control Area - CA) and four fragments with different reforestation ages, in Paraiba State. The latter fragments have undergone mining activities, and were reforested in 1989, 1997, 2001, and 2003. Four expeditions sampled the avifauna from November 2006 until April 2008. Each expedition had a sampling effort of 2700 net. $\mathrm{m}^{2}$. Statistical tests verified richness differences between the studied areas, as well as in the composition of functional groups. The study recorded a total of 89 bird species. The area reforested longer ago showed the highest richness $(n=51 \mathrm{spp}$.). Species richness was not statistically significant among the CA and reforested areas. Similarity analysis indicated that reforested areas share a large amount of species, and species composition differ largely in CA. This differentiation is explained by the significant presence of frugivores, nectarivores, and leaf and understory insectivores. Changes in species richness and composition in degraded areas are expected. Reforested areas usually have a smaller number of forest-dependent species due to lower resource availability. Reforestation is an important conservation strategy for degraded restinga forest. However, there is a need of management measures promoting the enrichment of these areas and resource availability for forest-dependent species.
\end{abstract}

Keywords: Forest dependence, atlantic forest, environmental restoration, functional groups.

\section{Comunidade de aves em áreas de restinga reflorestadas}

\begin{abstract}
Resumo
A fragmentação é uma das causas da diminuição da biodiversidade, principalmente em áreas de Floresta Atlântica. Este estudo avaliou as diferenças na riqueza e estrutura de grupos funcionais na ornitofauna de um fragmento nativo de floresta de restinga (Área Controle - AC) e quatro fragmentos com diferentes idades de reflorestamento (reflorestados em 1989, 1997, $2001 \mathrm{e}$ 2003). O levantamento da avifauna ocorreu entre novembro de 2006 e abril de 2008 e totalizou um esforço de 2700 rede. $\mathrm{m}^{2}$, por expedição. Foram registradas 89 espécies em todo o estudo. A área com a maior idade de reflorestamento deteve a maior riqueza $(\mathrm{n}=51 \mathrm{spp}$.). As diferenças entre as riquezas de $\mathrm{AC}$ e as áreas reflorestadas não foi estatisticamente significante. A análise de similaridade apontou um grande compartilhamento de espécies entre as áreas reflorestadas e uma diferenciação em AC. Essa diferenciação é explicada pela presença de espécies dependentes de floresta em AC. Mudanças na riqueza e composição de espécies em áreas degradadas são esperadas. Áreas reflorestadas normalmente apresentam menos espécies dependentes de florestas devido à deficiência de recursos disponíveis. Reflorestamentos são estratégias de conservação importantes, contudo há a necessidade de medidas que promovam o enriquecimento destas áreas e disponibilização de recursos para espécies dependente de ambientes florestais.
\end{abstract}

Palavras-chave: Dependência de floresta, floresta atlântica, restauração ambiental, grupos funcionais.

\section{Introduction}

In Brazil, landscape fragmentation has been a major cause of environmental degradation and decreased biological diversity (Machado, Drummond \& Paglia, 2008). The
Brazilian Atlantic Forest has undergone a long process of fragmentation over the last centuries, resulting in loss of habitat and landscape change. As a consequence, approximately $84 \%$ of its fragments have an area smaller 
than 50 ha (Ribeiro, Metzger, Martensen, Ponzoni \& Hirota, 2009; Melo, Arroyo-Rodriguez, Fahrig, Martinez-Ramos \& Tabarelli, 2013).

The Atlantic Forest has only $11.45 \%$ of its original coverage (Ribeiro et al., 2009). In northeast Brazil, original coverage is less than $5 \%$. This region is highly fragmented, especially due to industrial sugarcane processing, real estate speculation, and mining activities (Ribeiro et al., 2009). The main phytophysiognomies found are the restinga and board formations (Duré, Barbosa, Gadelha-Neto, Lima \& Lima, 2018).

Historically, forest fragmentation and selective logging have been identified as the main causes of deleterious effects on bird communities (Bierregard \& Lovejoy, 1989; Gimenes \& Anjos, 2003; Moura et al., 2014; Boesing, Nichols \& Metzger, 2018). Strategies to reduce species loss in these fragments include their protection, enrichment, and restoration, besides actions that allow connectivity between them (Brancalion, Melo, Tabarelli \& Rodrigues, 2013). In Brazil, the "Atlantic Forest Law" restricts the use of natural remnants of this biome and has a key role in restoring degraded areas (Calmon et al., 2011). Native forest fragments located close to restored areas prove to be important due to their potential to reduce edge effects and provide additional habitats, reducing the chances of future extinction (Santos-Junior, Marques, Lima \& Anjos, 2016). Moreover, these areas provide propagules of colonizing plants, and animals capable of occupying reforested environments. However, several studies have pointed out different responses among different taxonomic groups (Gibson et al., 2011).

Regarding birds, studies on avifauna diversity, richness, and composition seek to analyze ecological factors that interfere with environmental dynamics, such as changing of habitats in a natural or anthropogenic way. Habitat heterogeneity and the complexity of the vegetation structure directly affect the richness of forest-dependent species (Munro et al., 2011) and species with different ecological needs (MacArthur \& MacArthur, 1961). As a consequence of habitat loss, loss of variability in the vegetation structure leads to loss of diversity of this taxocenosis (Donner, Ribic \& Probst, 2010). Species sensitive to habitat changes are rare in secondary forest environments (Stratford \& Stouffer, 2013).

This study evaluates differences in avifauna richness and analyzes the structure of functional groups in a restinga forest fragment and four fragments with different reforestation ages, verifying the efficiency of reforestation actions conducted in the area.

\section{Materials and Methods}

\section{Study area}

The study was carried out in the mining area of the Cristal Mineração do Brasil LTDA Group, in a restinga area located in Mataraca city $\left(6^{\circ} 29^{\prime} 40.01^{\prime \prime} \mathrm{S}, 34^{\circ} 58^{\prime} 41.78^{\prime} \mathrm{W}\right)$, in the extreme northern coast of Paraíba State. The area is located in the drainage region of the Guaju River watershed, and covers 250 ha among portions of native forests, reforested areas, and sites subject to mining activities (Figure 1).
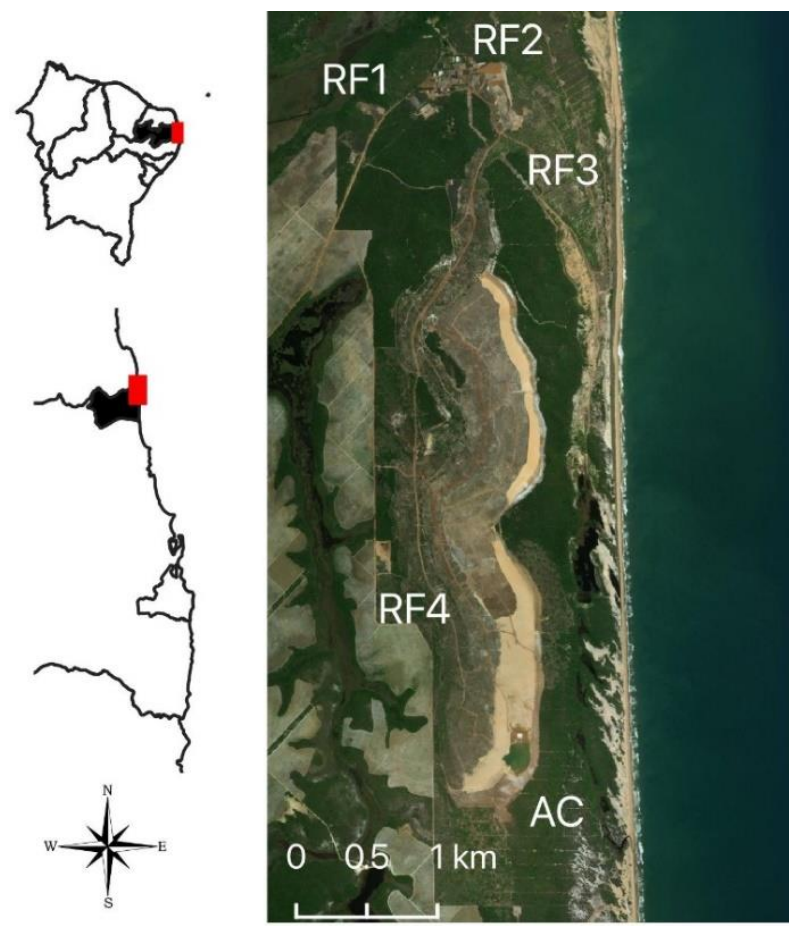

Figure 1. Restinga area on the northern coast of Paraíba State, with indications of the studied fragments (control area (CA) and reforested area (RF1 - RF4).

After mining, the dunes are rebuilt and the recovery program is applied. This process includes planting seedlings of selected tree species, implementing physical and biological windbreaks, sprinkler irrigation, soil enrichment, and addition of $40 \mathrm{~cm}$ of soil from already explored areas, which was stocked prior to mining (Duré et al., 2018). The reforestation program started in 1989 with the planting of 27 tree species (native and exotic), without any pattern of spacing or number of individuals. Propagules of herbaceous species common in the locality were also planted (Cunha, Fontes, Oliveira \& Oliveira-Filho, 2003).

Management of native species, including crowning, vine removal, and pruning, was carried out until plants reached a size that would allow them to overcome exotic species (Duré et al., 2018).

In the present study, we selected five areas within the mining complex, which consist of a native, unmined fragment, called the Control Area (CA), and four fragments subject to mining, with different reforestation ages (1989, 1997, 2001, and 2003), named, respectively, RF1, RF2, RF3, and RF4 (Figure 1). The fragments are characterized below.

Reports produced by the company itself point to the occurrence of 28 plant species exclusively in the control area, and 21 other species exclusively in the reforestation areas. Both the number of species and the number of plant individuals in the control area (average of 16.66 species and 66.33 individuals per $200 \mathrm{~m}^{2}$ plot) are much higher than those observed in reforested areas (RF1: $10.00 \mathrm{spp}$. and $33.66 \mathrm{ind} / 200 \mathrm{~m}^{2}$; RF2: $8.33 \mathrm{spp}$. and $26.66 \mathrm{ind} / 200 \mathrm{~m}^{2}$; RF3: $5.00 \mathrm{spp}$. and $25.66 \mathrm{ind} / 200 \mathrm{~m}^{2}$; RF4: $2.66 \mathrm{spp}$. and 13.00 ind $/ 200 \mathrm{~m}^{2}$ ). The main plant species found in reforested areas 
are Anacardium occidentale L. and Tocoyena selloana K. Schum., the latter not having been recorded in RF4. The Control Area does not contain the two most abundant species observed in reforested areas, having Eugenia uniflora L. and Maytenus sp. as the most abundant species, both of which occur exclusively in this fragment.

Reforested areas have an average area of 73 ha, while the control area measures 170 ha. The average distance between the centers of each area and the studied reforestation area was $3.71 \mathrm{~km}$. The nearest forest fragment is the RPPN Mata da Estrela, in Baia Formosa city, Rio Grande do Norte State, located $16 \mathrm{~km}$ away from the studied area. Data regarding geometry and the distance between the central point of each studied area are presented in Table 1.

Table 1. Area (ha), perimeter $(\mathrm{km})$, and distance $(\mathrm{km})$ between forest fragments in a restinga area on the northern coast of Paraíba State. CA: Control area; RF1, RF2, RF3, and RF4: Areas reforested in 1989, 1997, 2001, and 2003, respectively.

\begin{tabular}{|c|c|c|c|c|c|c|c|}
\hline \multirow{2}{*}{$\begin{array}{c}\text { Studied } \\
\text { area }\end{array}$} & \multirow{2}{*}{ Area } & \multirow{2}{*}{ Perim. } & \multicolumn{5}{|c|}{ Distance } \\
\hline & & & CA & RF1 & RF2 & RF3 & RF4 \\
\hline $\mathrm{CA}$ & 170 & 7.44 & 0 & & & & \\
\hline RF1 & 45 & 5.49 & 5.56 & 0 & & & \\
\hline RF2 & 47 & 2.73 & 5.97 & 1.09 & 0 & & \\
\hline RF3 & 67 & 4.45 & 5.08 & 1.39 & 0.97 & 0 & \\
\hline RF4 & 133 & 7.63 & 1.93 & 3.63 & 4.11 & 3.28 & 0 \\
\hline
\end{tabular}

\section{Data survey}

The local avifauna was surveyed through four expeditions, two in the dry season (November 2006 and November 2007) and two in the rainy season (April 2007 and April 2008). The survey included direct observations with the aid of binoculars (7 X $35 \mathrm{~mm}$ ), identification of vocalizations through recordings, and mist-net captures. For that purpose, three 1-ha sampling plots were established in each of the reforestation areas and in the control area. Sampling included 24 point counts in each sampling area, which lasted 10 minutes and were at least 150 meters apart. Additionally, 18 fog nets $(12 \mathrm{~m}$ x $2.5 \mathrm{~m}$ and 36-mm mesh) were used, distributed in three rows with six nets each, randomly distributed within the plots, adding up to a total effort of 2700 net. $\mathrm{m}^{2}$ per expedition. Field activities were duly authorized through the SNA/CEMAVE/SISBio-proj 3029 project.

\section{Classification and categorization of species}

The birds were identified with specialized field guides and marked with metal washers provided by the Brazilian National Center for Bird Research and Conservation CEMAVE/ICMBIO. Species were classified according to the systematic order suggested by the Brazilian Ornithological Records Committee (Piacentini et al., 2015).

Species were categorized for their dependence on forest environments according to Parker et al. (1996), and for their functional groups according to Wilman et al. (2014) and Araujo \& Silva (2017). Forest dependence is classified as follows: (1) dependent: species that occur only in forest environments; (2) semidependent: species that occur in the mosaic formed between forests and open and semiopen vegetation formations; (3) independent: species associated only with open areas.

Functional groups were defined from diet and foraging stratum. The defined categories were: carnivores (CAR), detritivores (SCV), small frugivores (weight $\leq 80.0 \mathrm{~g}$; SFR), large frugivores (weight $\geq 80.1 \mathrm{~g}$; LFR), nectarivores (NEC), edge/open area granivores (EGR), terrestrial granivores (TGR), omnivores (OMN), omnivores/insectivores (OIN), canopy insectivores (CIN), trunk and branch insectivores (TTI), leaf insectivores (LIN), understory insectivores (UIN), terrestrial insectivores (TIN). Categorizations were based on Wilman et al. (2014) and Araujo \& Silva (2017).

\section{Data analysis}

All statistical analyses were computed in R software. To test the differences between species richness in the studied areas, the "c $2 \mathrm{cv}$ " function of the "rich" package was used, which verified the statistical significance of the values observed in the studied areas (see Rossi, 2011 for details). To test whether the avifauna composition in the reforested areas with the longest recovery time is similar to that of the control area, the Morisita-Horn similarity index was used through the "vegdist" function of the "vegan" package in R software (Oksanen et al., 2019). To visualize changes in the composition of functional groups between the studied areas, principal component analysis was used through the "fviz_pca" function of the "factoextra" package, also in R software (Kassambara \& Mundt, 2016).

\section{Results and Discussion}

A total of 89 bird species were recorded in the five areas studied (Table 2). The area reforested in 1989 (RF1) had a higher species richness than the control area (51 and 48, respectively), and the area with the second longest reforestation time (1997 - RF2) showed 45 species, only three less than CA (Figure 2). The difference in the number of species between the Control Area (CA) and the reforested areas is within the limit expected by the null model hypothesis, i.e., it is not statistically significant (Table 3).

Principal component analysis revealed two important axes, which together explain $52.1 \%$ of the variance in the structure of functional groups (Figure 4). Positive values on axis 1 are associated with the areas with the largest number of leaf insectivores (LIN), understory insectivores (UIN), and trunk and branch insectivores (TTI), while negative values on this axis refer to areas with higher concentration of edge/open area granivores (EGR) and terrestrial insectivores (TIN).

In axis 2, positive values are associated with areas with the greatest richness of understory insectivores, nectarivores (NEC), and omnivores with a preference for insects (omnivores-insectivores - OIN). In turn, negative values are associated with areas having carnivores (CAR), omnivores $(\mathrm{OMN})$, detritivores (SCV), and terrestrial and canopy insectivores (TIN and CIN, respectively). Species classified as terrestrial insectivores (TIN) are present only in the most recently reforested area (RF4). In contrast, no frugivores were recorded in this area. Species classified as frugivores (SFR or LFR) were more frequent in the control area (CA). 
Table 2. Systematic list of bird species from a restinga area on the northern coast of Paraíba State, showing the number of records in the fragments in which they occur and their functional groups (FG).

\begin{tabular}{|c|c|c|c|c|c|c|}
\hline Specie & $\mathrm{CA}$ & RF1 & RF2 & RF3 & RF4 & FG \\
\hline Crypturellus parvirostris (Wagler, 1827) & 0 & 0 & 3 & 0 & 2 & TGR \\
\hline Penelope superciliaris Temminck, 1815 & 3 & 0 & 1 & 0 & 0 & LFR \\
\hline Ortalis guttata (Spix, 1825) & 2 & 2 & 0 & 0 & 0 & LFR \\
\hline Ardea alba Linnaeus, 1758 & 0 & 0 & 0 & 0 & 1 & OMN \\
\hline Cathartes aura (Linnaeus, 1758) & 4 & 3 & 8 & 2 & 2 & $\mathrm{SCV}$ \\
\hline Coragyps atratus (Bechstein, 1793) & 1 & 2 & 0 & 0 & 0 & SCV \\
\hline Rupornis magnirostris (Gmelin, 1788) & 0 & 1 & 6 & 2 & 2 & CAR \\
\hline Buteo nitidus (Latham, 1790) & 1 & 0 & 0 & 0 & 1 & CAR \\
\hline Aramides cajaneus (Statius Muller, 1776) & 1 & 1 & 0 & 0 & 0 & OMN \\
\hline Vanellus chilensis (Molina, 1782) & 0 & 0 & 0 & 0 & 4 & TIN \\
\hline Columbina passerina (Linnaeus, 1758) & 0 & 1 & 0 & 2 & 19 & EGR \\
\hline Columbina talpacoti (Temminck, 1810) & 1 & 6 & 6 & 17 & 32 & EGR \\
\hline Columbina squammata (Lesson, 1831) & 0 & 0 & 1 & 0 & 0 & EGR \\
\hline Leptotila rufaxilla (Richard \& Bernard, 1792) & 9 & 10 & 8 & 6 & 0 & TGR \\
\hline Geotrygon montana (Linnaeus, 1758) & 1 & 0 & 0 & 0 & 0 & TGR \\
\hline Piaya cayana (Linnaeus, 1766) & 0 & 0 & 2 & 0 & 0 & OMN \\
\hline Coccyzus americanus (Linnaeus, 1758) & 0 & 0 & 1 & 1 & 0 & OMN \\
\hline Crotophaga ani Linnaeus, 1758 & 0 & 0 & 0 & 4 & 11 & $\mathrm{OMN}$ \\
\hline Phaethornis ruber (Linnaeus, 1758) & 4 & 0 & 0 & 0 & 0 & $\mathrm{NEC}$ \\
\hline Phaethornis pretrei (Lesson \& Delattre, 1839) & 1 & 0 & 0 & 1 & 0 & NEC \\
\hline Chrysolampis mosquitus (Linnaeus, 1758) & 0 & 0 & 0 & 0 & 1 & NEC \\
\hline Chlorestes notata (Reich, 1793) & 1 & 0 & 0 & 0 & 0 & NEC \\
\hline Chlorostilbon lucidus (Shaw, 1812) & 0 & 3 & 0 & 2 & 0 & $\mathrm{NEC}$ \\
\hline Amazilia leucogaster (Gmelin, 1788) & 0 & 0 & 0 & 1 & 0 & NEC \\
\hline Amazilia fimbriata (Gmelin, 1788) & 0 & 0 & 0 & 0 & 2 & NEC \\
\hline Trogon curucui Linnaeus, 1766 & 3 & 0 & 0 & 0 & 0 & SFR \\
\hline Galbula ruficauda Cuvier, 1816 & 2 & 6 & 3 & 0 & 0 & UIN \\
\hline Nystalus maculatus (Gmelin, 1788) & 0 & 3 & 2 & 2 & 0 & UIN \\
\hline Picumnus fulvescens Stager, 1961 & 0 & 0 & 1 & 0 & 0 & TTI \\
\hline Celeus flavescens (Gmelin, 1788) & 2 & 2 & 4 & 0 & 0 & TTI \\
\hline Caracara plancus (Miller, 1777) & 0 & 2 & 0 & 0 & 3 & OMN \\
\hline Milvago chimachima (Vieillot, 1816) & 2 & 0 & 0 & 0 & 0 & OMN \\
\hline Formicivora grisea (Boddaert, 1783) & 19 & 15 & 10 & 2 & 0 & LIN \\
\hline Dysithamnus mentalis (Temminck, 1823) & 2 & 0 & 0 & 0 & 0 & LIN \\
\hline Herpsilochmus atricapillus Pelzeln, 1868 & 6 & 2 & 0 & 0 & 0 & LIN \\
\hline Herpsilochmus pectoralis Sclater, 1857 & 3 & 0 & 0 & 0 & 0 & LIN \\
\hline Thamnophilus pelzelni Hellmayr, 1924 & 6 & 3 & 1 & 0 & 0 & LIN \\
\hline Taraba major (Vieillot, 1816) & 2 & 1 & 0 & 0 & 0 & OIN \\
\hline Conopophaga lineata (Wied, 1831) & 0 & 2 & 0 & 0 & 0 & OIN \\
\hline Xiphorhynchus guttatus (Lichtenstein, 1820) & 6 & 0 & 0 & 0 & 0 & UIN \\
\hline Dendroplex picus (Gmelin, 1788) & 1 & 0 & 0 & 0 & 0 & TTI \\
\hline Xenops minutus (Sparrman, 1788) & 9 & 3 & 2 & 0 & 0 & TTI \\
\hline Synallaxis frontalis Pelzeln, 1859 & 2 & 0 & 0 & 0 & 0 & TTI \\
\hline Crypturellus parvirostris (Wagler, 1827) & 0 & 1 & 0 & 0 & 0 & LIN \\
\hline
\end{tabular}

CA: Control area; RF1, RF2, RF3, and RF4: Areas reforested in 1989, 1997, 2001, and 2003, respectively. Functional groups: carnivores (CAR), detritivores (SCV), small frugivores (weight $\leq 80.0 \mathrm{~g}$; SFR), large frugivores (weight $\geq 80.1 \mathrm{~g}$; LFR), nectarivores (NEC), edge/open area granivores (EGR), terrestrial granivores (TGR), omnivores (OMN), omnivores/insectivores (OIN), canopy insectivores (CIN), trunk and branch insectivores (TTI), leaf insectivores (LIN), understory insectivores (UIN), terrestrial insectivores (TIN). 
Table 2. Continuation.

\begin{tabular}{|c|c|c|c|c|c|c|}
\hline Specie & $\mathrm{CA}$ & RF1 & RF2 & RF3 & RF4 & FG \\
\hline Neopelma pallescens (Lafresnaye, 1853) & 24 & 1 & 0 & 0 & 0 & TTI \\
\hline Chiroxiphia pareola (Linnaeus, 1766) & 5 & 0 & 0 & 0 & 0 & SFR \\
\hline Pachyramphus polychopterus (Vieillot, 1818) & 0 & 0 & 1 & 0 & 0 & OIN \\
\hline Platyrinchus mystaceus Vieillot, 1818 & 2 & 0 & 0 & 0 & 0 & LIN \\
\hline Tolmomyias flaviventris (Wied, 1831) & 1 & 8 & 7 & 1 & 0 & LIN \\
\hline Todirostrum cinereum (Linnaeus, 1766) & 0 & 5 & 5 & 0 & 0 & LIN \\
\hline Hemitriccus zosterops (Pelzeln, 1868) & 1 & 0 & 0 & 0 & 0 & LIN \\
\hline Hemitriccus margaritaceiventer (d'Orbigny \& Lafresnaye, 1837) & 1 & 2 & 5 & 9 & 0 & LIN \\
\hline Camptostoma obsoletum (Temminck, 1824) & 0 & 1 & 3 & 2 & 1 & LIN \\
\hline Elaenia flavogaster (Thunberg, 1822) & 1 & 1 & 1 & 2 & 1 & CIN \\
\hline Elaenia cristata Pelzeln, 1868 & 0 & 1 & 3 & 0 & 2 & CIN \\
\hline Phaeomyias murina (Spix, 1825) & 0 & 0 & 1 & 4 & 2 & CIN \\
\hline Myiarchus ferox (Gmelin, 1789) & 0 & 2 & 1 & 0 & 0 & $\mathrm{CIN}$ \\
\hline Myiarchus tyrannulus (Statius Muller, 1776) & 0 & 9 & 11 & 3 & 0 & CIN \\
\hline Pitangus sulphuratus (Linnaeus, 1766) & 0 & 3 & 20 & 12 & 6 & $\mathrm{OMN}$ \\
\hline Myiozetetes similis (Spix, 1825) & 0 & 0 & 2 & 0 & 0 & CIN \\
\hline Tyrannus melancholicus Vieillot, 1819 & 0 & 0 & 1 & 2 & 3 & CIN \\
\hline Lathrotriccus euleri (Cabanis, 1868) & 1 & 3 & 0 & 1 & 0 & UIN \\
\hline Cyclarhis gujanensis (Gmelin, 1789) & 6 & 8 & 5 & 3 & 0 & OMN \\
\hline Hylophilus amaurocephalus (Nordmann, 1835) & 1 & 2 & 6 & 3 & 0 & CIN \\
\hline Vireo chivi (Vieillot, 1817) & 11 & 17 & 18 & 14 & 3 & LIN \\
\hline Stelgidopteryx ruficollis (Vieillot, 1817) & 0 & 1 & 4 & 0 & 0 & UIN \\
\hline Progne tapera (Vieillot, 1817) & 3 & 12 & 0 & 0 & 0 & CIN \\
\hline Troglodytes musculus Naumann, 1823 & 0 & 1 & 0 & 0 & 0 & LIN \\
\hline Pheugopedius genibarbis (Swainson, 1838) & 9 & 2 & 0 & 0 & 0 & UIN \\
\hline Cantorchilus longirostris (Vieillot, 1819) & 0 & 0 & 1 & 0 & 0 & UIN \\
\hline Polioptila plumbea (Gmelin, 1788) & 4 & 6 & 11 & 11 & 2 & CIN \\
\hline Turdus flavipes Vieillot, 1818 & 0 & 0 & 0 & 2 & 0 & SFR \\
\hline Turdus leucomelas Vieillot, 1818 & 2 & 17 & 5 & 1 & 1 & OMN \\
\hline Mimus gilvus (Vieillot, 1807) & 0 & 0 & 0 & 0 & 2 & OIN \\
\hline Arremon taciturnus (Hermann, 1783) & 7 & 0 & 0 & 0 & 0 & UIN \\
\hline Basileuterus culicivorus (Deppe, 1830) & 0 & 1 & 2 & 1 & 0 & LIN \\
\hline Myiothlypis flaveola Baird, 1865 & 20 & 1 & 0 & 1 & 0 & LIN \\
\hline Icterus cayanensis (Linnaeus, 1766) & 0 & 2 & 4 & 0 & 0 & CIN \\
\hline Tangara sayaca (Linnaeus, 1766) & 0 & 9 & 3 & 3 & 0 & OIN \\
\hline Tangara palmarum (Wied, 1821) & 0 & 3 & 2 & 6 & 0 & OIN \\
\hline Tangara cayana (Linnaeus, 1766) & 0 & 8 & 3 & 3 & 0 & OIN \\
\hline Sicalis flaveola (Linnaeus, 1766) & 0 & 1 & 0 & 0 & 0 & TGR \\
\hline Volatinia jacarina (Linnaeus, 1766) & 0 & 0 & 4 & 3 & 10 & EGR \\
\hline Lanio cristatus (Linnaeus, 1766) & 4 & 0 & 0 & 0 & 0 & UIN \\
\hline Tachyphonus rufus (Boddaert, 1783) & 3 & 2 & 2 & 0 & 1 & UIN \\
\hline Dacnis cayana (Linnaeus, 1766) & 4 & 1 & 14 & 5 & 3 & NEC \\
\hline Coereba flaveola (Linnaeus, 1758) & 10 & 10 & 13 & 17 & 0 & NEC \\
\hline Saltator maximus (Statius Muller, 1776) & 0 & 1 & 0 & 0 & 0 & OIN \\
\hline Thlypopsis sordida (d'Orbigny \& Lafresnaye, 1837) & 0 & 2 & 0 & 0 & 0 & OIN \\
\hline Euphonia chlorotica (Linnaeus, 1766) & 1 & 0 & 0 & 0 & 0 & SFR \\
\hline
\end{tabular}

CA: Control area; RF1, RF2, RF3, and RF4: Areas reforested in 1989, 1997, 2001, and 2003, respectively. Functional groups: carnivores (CAR), detritivores (SCV), small frugivores (weight $\leq 80.0 \mathrm{~g}$; SFR), large frugivores (weight $\geq 80.1 \mathrm{~g}$; LFR), nectarivores (NEC), edge/open area granivores (EGR), terrestrial granivores (TGR), omnivores (OMN), omnivores/insectivores (OIN), canopy insectivores (CIN), trunk and branch insectivores (TTI), leaf insectivores (LIN), understory insectivores (UIN), terrestrial insectivores (TIN). 


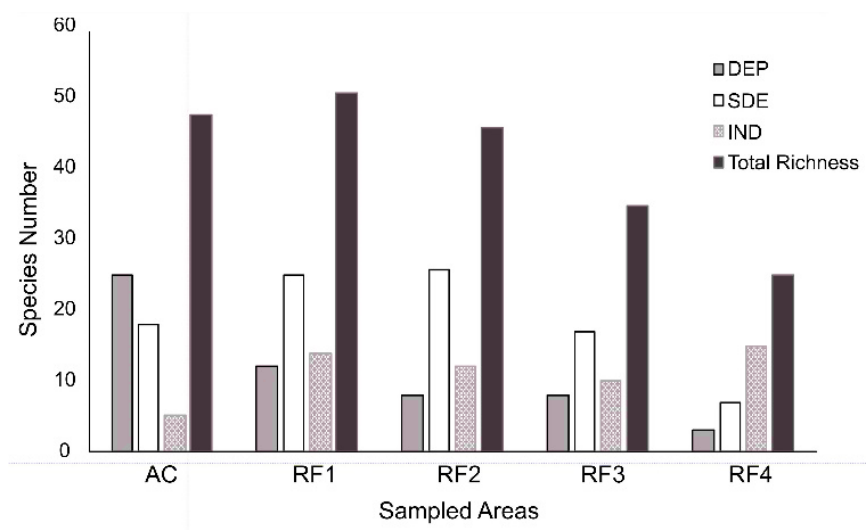

Figure 2. Total species richness and habitat use in reforested fragments and a control fragment in a restinga area on the northern coast of Paraíba State. CA: Control area; RF1 (reforested in 1989), RF2 (reforested in 1997), RF3 (reforested in 2001), and RF4 (reforested in 2003). DEP: Forestdependent bird species; SDE: Semidependent forest bird species; IND: Forest-independent bird species.

Table 3. Permutation analysis of bird species richness in reforested fragments (RF1 to RF4) and a control fragment (CA) in a restinga area on the northern coast of Paraíba State.

\begin{tabular}{lcc}
\hline \multicolumn{1}{c}{ Area } & $\begin{array}{c}\text { Differences } \\
\text { in N }\end{array}$ & $p$ \\
\hline CA with All reforestations & 25 & 0.891 \\
CA with RF1 & 3 & 0.406 \\
CA with RF2 & 3 & 0.406 \\
CA with RF3 & 13 & 0.257 \\
CA with RF4 & 23 & 0.139 \\
\hline N = Number of bird species & &
\end{tabular}

Similarity analysis showed a faunal relationship between reforested areas, and a differentiation in the composition of CA species (Figure 3). This difference can be explained by the higher presence of forest-dependent species in CA, such as the pale-bellied Tyrant-Manakin (Neopelma pallescens), and the high presence of forest-independent species such as the great

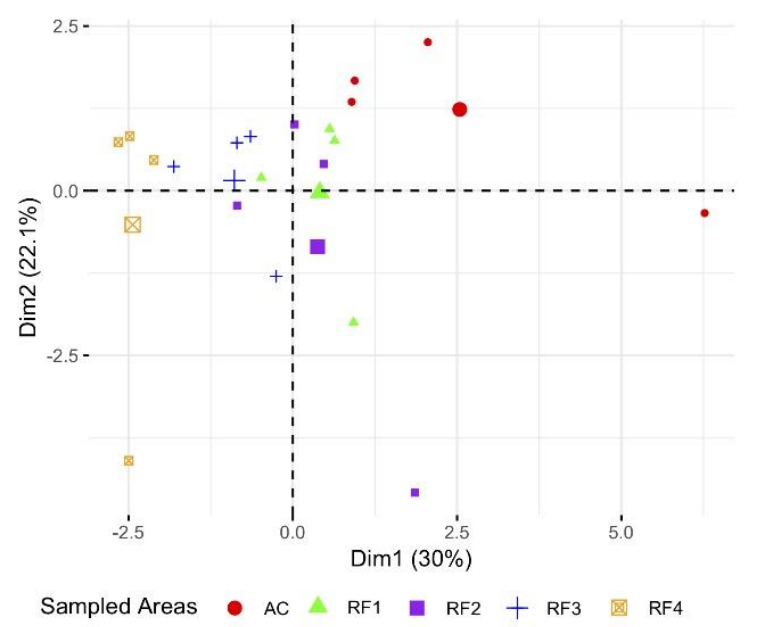

kiskadee (Pitangus sulphuratus) in reforested areas, especially those more recently reforested (see Figure 2).

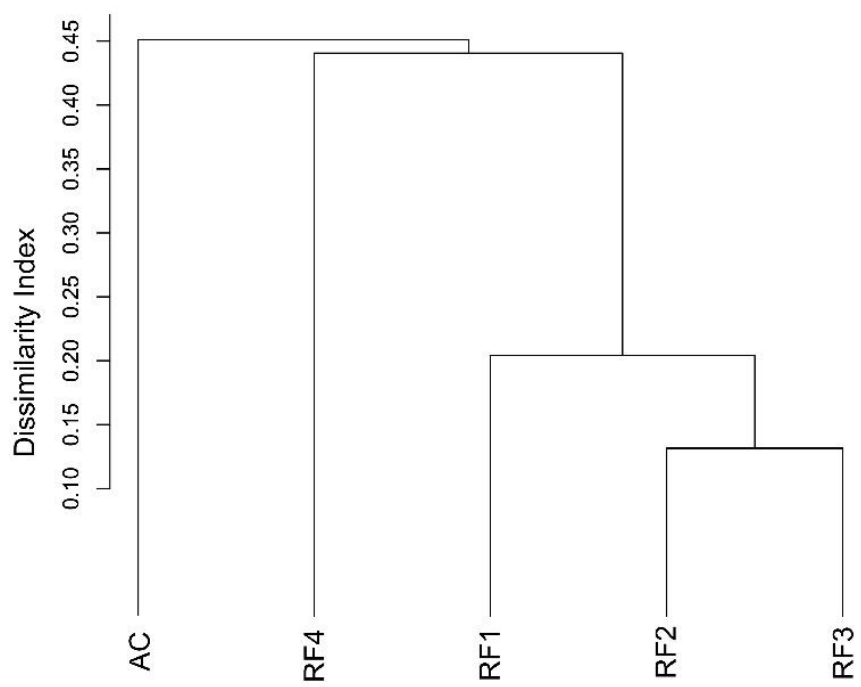

Figure 3. Hierarchical cluster analysis of the absence/presence of bird species (Morisita-Horn dissimilarity index) in the five areas studied. CA: Control area; RF1 (reforested in 1989), RF2 (reforested in 1997), RF3 (reforested in 2001), and RF4 (reforested in 2003).

Bird species richness was very close between the native forest fragment (CA) and the areas reforested longer ago (RF1 and RF2), being higher in RF1. However, similarity analysis showed differences in species composition between the studied areas. This is partly explained by the higher richness of forest-dependent species in CA as well as by the predominance of typical open-area species in reforested areas, mainly those most recently reforested. In general, species composition in reforested areas is different from the species composition prior to disturbance or when compared to a reference fragment. The main explanation is the time that reforested areas would need to recover specific microhabitats such as those needed for forest-dependent species (Stanturf, Palik \& Dumroese, 2014).

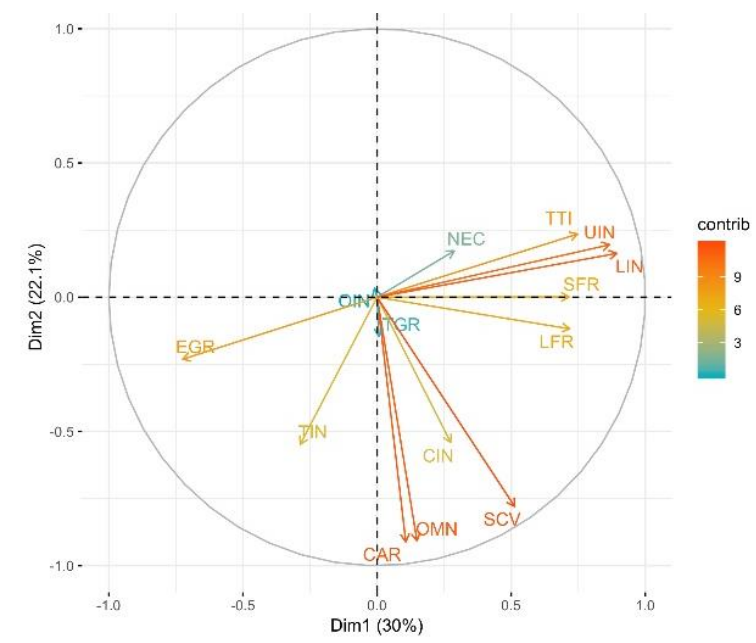

Figure 4. (A) Principal component analysis of the structure of functional groups of birds in the Control Area (CA) and reforested areas (RF1, RF2, RF3, and RF4). (B) Correlation circle indicating the importance of each functional group in the first and second 
axes of the principal components. Functional groups as described in Table 1.

More specifically, birds tend to respond well in reforested areas, presenting a species richness close to that of the reference community, but with different taxocenosis (Munro et al., 2011; Catterall, Freeman, Kanowski \& Freebody, 2012). The control area showed a predominance of forest-dependent over forestindependent species, while semidependent or independent species predominate in reforested areas.

Noticing changes in bird richness and composition in locations subject to high anthropogenic pressure, such as the studied areas, is no surprise. This is because we know that environmental changes directly affect the ecological traits of species in a given location and that the communities that live there respond in complex ways to these changes (Banks-Leite, Ewers \& Metzger, 2013; Supp \& Ernest, 2014). The community may respond to habitat decrease/fragmentation with species loss without a systematic decline in diversity (Banks-Leite et al., 2013; Supp \& Ernest, 2014). This phenomenon occurs because species substitution changes the ecological functions of a community (Lepš, Bello, Šmilauer \& Doležal, 2011). In this way, deforested areas can promote different ecological functions, but not necessarily less functions (De Coster, BanksLeite \& Metzger, 2015).

Reforested areas usually have a smaller number of forestdependent species due to the lack of resources and adequate locations for building nests (Moura et al., 2014). Species that recolonize these areas tend to be opportunistic and generalist (Critescu, Frère \& Banks, 2012; Santos-Junior et al., 2016). This aspect leads us to propose measures for environmental enrichment, thus increasing the availability of habitats for less generalist forest-dependent species.

It is important to remember that bird community composition changes along with reforestation time (Catterall et al., 2012). Notwithstanding, colonization of reforested areas by new species does not compensate for the absence of native species, since new species do not meet conservationist concerns (Moura et al., 2014). Therefore, monitoring actions should be prioritized to assess whether these areas are becoming capable of receiving a higher number of forest-dependent species (Santos-Junior et al., 2016).

\section{Conclusion}

Our results suggest that reforested areas can provide various habitats and resources, mainly in highly fragmented sites, but only for specific groups of birds. Bird species that prefer forest habitats are less frequent and less abundant in reforested areas, even when the reforestation time is long.

We understand that the recovery of areas through reforestation is an important conservation strategy in fragmented landscapes. However, there is a need for management measures that promote the enrichment of these areas and the availability of resources for forest-dependent species. In addition, the Atlantic Forest of northeastern Brazil is one of the most threatened landscapes in the world. That is why systematic mapping of ecological and conservation knowledge for this region, including threats and barriers to conservation, could identify preferences, flaws, and research priorities of value to researchers and conservationists.

\section{References}

Araujo, H.F.P. \& Silva, J.M.C. (2017). The Avifauna of the Caatinga: Biogeography, Ecology, and Conservation. In J.M.C. Silva, I. Leal, \& M. Tabarelli (Ed.). Biodiversity, Ecosystems Services and Sustainable Development in Caatinga: The Largest Tropical Dry Forest Region in South America. (pp. 181-210). Berlin: Springer-Verlag.

Banks-Leite, C., Ewers, R. M. \& Metzger J. P. (2013). The confounded effects of habitat disturbance at the local, patch and landscape scale on understorey birds of the Atlantic Forest: Implications for the development of landscape-based indicators. Ecological indicators, 31 , 82-88. doi: 10.1016/j.ecolind.2012.04.015

Bierregard, R. O. \& Lovejoy, T. E. (1989). Effects of forest fragmentation on Amazonian understory bird communities. Acta amazonica, 19, 215 241. doi: 10.1590/1809-43921989191241

Boesing, A. L., Nichols, E. \& Metzger, J. P. (2018). Biodiversity extinction thresholds are modulated by matrix type. Ecography, 41(9), 15201533. doi: 10.1111/ecog.03365

Brancalion, P. H., Melo, F. P., Tabarelli, M. \& Rodrigues, R. R. (2013). Restoration reserves as biodiversity safeguards in human-modified landscapes. Natureza \& Conservação, 11(2), 1-5. doi: 10.4322/natcon.2013.029

Calmon, M., Brancalion, P. H., Paese, A., Aronson, J., Castro, P., Silva, S. C. \& Rodrigues, R. R. (2011). Emerging threats and opportunities for large-scale ecological restoration in the Atlantic Forest of Brazil. Restoration Ecology, 19(2), 154-158. doi: 10.1111/j.1526100X.2011.00772.x

Catterall, C. P., Freeman, A. N. D., Kanowski, J. \& Freebody, K. (2012). Can active restoration of tropical rainforest rescue biodiversity? A case with bird community indicators. Biological Conservation, 146(1), 5361. doi: 10.1016/j.biocon.2011.10.033

Cristescu, R. H., Frère, C. \& Banks, P. B. (2012). A review of fauna in mine rehabilitation in Australia: current state and future directions. Biological Conservation, 149(1), 60-72. doi: 10.1016/j.biocon.2012.02.003

Cunha, L. O., Fontes, M. A. L., Oliveira, A. D. \& Oliveira-Filho, A. T. (2003). Análise multivariada da vegetação como ferramenta para avaliar a reabilitação de dunas litorâneas mineradas em Mataraca, Paraíba, Brasil. Revista Árvore, 27(4), 503-515. doi: 10.1590/S010067622003000400011

De Coster, G., Banks-Leite, C. \& Metzger, J. P. (2015). Atlantic forest bird communities provide different but not fewer functions after habitat loss. Proceedings of the Royal Society B: Biological Sciences, 282(1811), 2014-2844. doi: 10.1098/rspb.2014.2844

Donner, D. M., Ribic, C. A. \& PROBST, J. R. (2010). Patch dynamics and the timing of colonization-abandonment events by male Kirtland's Warblers in an early succession habitat. Biological Conservation, 143(5), 1159-1167. doi: 10.1016/j.biocon.2010.02.023

Duré, R. C., Barbosa, M. R., Gadelha-Neto, P. C., Lima, I. B., \& Lima, J. R. (2018). Reabilitação florestal de dunas litorâneas pós-mineração no nordeste brasileiro. Gaia Scientia, 12(1). doi: 10.22478/ufpb.19811268.2018v12n1.36704

Gibson, L., Lee, T. M., Koh, L. P., Brook, B. W., Gardner, T. A., Barlow, J.,... \& Sodhi, N. S. (2011). Primary forests are irreplaceable for sustaining tropical biodiversity. Nature, 478(7369), 378-381. doi: 10.1038/nature10425

Gimenes, M. R. \& Anjos, L. (2003). Efeitos da fragmentação florestal sobre as comunidades de aves. Acta Scientiarum. Biological Sciences, 25(2), 391-402. doi: 10.4025/actascibiolsci.v25i2.2030

Kassambara, A. \& Mundt, F. (2016). Factoextra: extract and visualize the results of multivariate data analyses. $R$ package version, 1.3 . Recovered from http://www.sthda.com/english/rpkgs/factoextra/.

Lepš, J., de Bello, F., Šmilauer, P., \& Doležal, J. (2011). Community trait response to environment: disentangling species turnover vs intraspecific trait variability effects. Ecography, 34(5), 856-863. doi: 10.1111/j.1600-0587.2010.06904.x

MacArthur, R. H. \& MacArthur, J. W. (1961). On bird species diversity. Ecology, Washington, D.C., v. 42, n. 3, p. 594-598, 1961. doi: $10.2307 / 1932254$

Machado, A. B. M., Drummond, G. M. \& Paglia, A. P. (2008). Livro 
vermelho da fauna brasileira ameaçada de extinção. Belo Horizonte: Fundação Biodiversitas.

Melo, F. P. L., Arroyo-Rodriguez, V., Fahrig L., Martinez-Ramos, M. \& Tabarelli, M. (2013). On the hope for biodiversity-friendly tropical landscapes. Trends in ecology \& evolution, 28(8), 462-468. doi: 10.1016/j.tree.2013.01.001

Moura, N. G., Lees, A. C., Aleixo, A., Barlow, J., Dantas, S. M., Ferreira, J., Lima, M. F. \& Gardner, T. A. (2014). Two hundred years of local avian extinctions in Eastern Amazonia. Conservation biology, 28(5), 1271-1281. doi: 10.1111/cobi.12300

Munro, N. T., Fischer, J., Barrett, G., Wood, J., Leavesley, A., \& Lindenmayer, D. B. (2011). Bird's response to revegetation of different structure and floristics-are "restoration plantings" restoring bird communities? Restoration Ecology, 19(201), 223-235. doi: 10.1111/j.1526100X.2010.00703.x

Oksanen, J., Blanchet, F. G., Kindt, R., Legendre, P., O'Hara, R.B., Simpson, G. L., Solymos, P., Stevens, M. H. H., Wagner, H. (2019). vegan: Community Ecology Package. $R$ package version 2.5-6. Recovered from https://CRAN.R-project.org/package=vegan

Parker III, T.A., Stotz, D.F. \& Fitzpatrick, J.W., 1996. Ecological and distributional databases. In: Stotz, D.F., Fitzpatrick, J.W., Parker III, T.A. \& Moskovits, D.K. (Eds.), Neotropical Birds: Ecology and Conservation. The University of Chicago Press, Chicago, pp. 111-410.

Piacentini, V. Q., Aleixo, A., Agne, C. E., Maurício, G. N., Pacheco, J. F., Bravo, G. A., Brito, G. R. R., Naka, L. N., Olmos, F., Posso, S., Silveira. L. F., Betini, G. S., Carrano, E., Franz, I., Lees, A. C., Lima, L. M., Pioli, D., Schunck. F., Amaral, F. R., Bencke, G. A., Cohn-Haft, M., Figueiredo, L. F. A., Straube, F. C. \& Cesari, E. (2015). Annotated checklist of the birds of Brazil by the Brazilian Ornithological Records Committee/Lista comentada das aves do Brasil pelo Comitê Brasileiro de Registros Ornitológicos. Revista Brasileira de Ornitologia, 23(2), 91-298. Recovered from http://www.revbrasilornitol.com.br/BJO/article/view/1263

Ribeiro, M. C., Metzger, J. P., Martensen, A. C., Ponzoni, F. J. \& Hirota, M. M. (2009). The Brazilian Atlantic Forest: How much is left, and how is the remaining forest distributed? Implications for conservation. Biological conservation, 142(6), 1141-1153. doi: 10.1016/j.biocon.2009.02.021

Rossi, J. P. (2011). rich: an R package to analyse species richness. Diversity, 3(1), 112-120. https://doi.org/10.3390/d3010112

Santos-Junior, P. C. A., Marques, F. C., Lima, M. R. \& Anjos, L. (2016). The importance of restoration areas to conserve bird species in a highly fragmented Atlantic forest landscape. Natureza \& Conservação, 14(1), 1-7. doi: 10.1016/j.ncon.2016.03.001

Stanturf, J. A., PALIK, B. J. \& Dumroesem R. K. (2014). Contemporary forest restoration: a review emphasizing function. Forest Ecology and Management, 331, 292-323. doi: 10.1016/j.foreco.2014.07.029

Stratford, J. A. \& Stouffer, P. C. (2013). Microhabitat associations of terrestrial insectivorous birds in Amazonian rainforest and second-growth forests. Journal of Field Ornithology, 84(1), 1-12. doi: 10.1111/jofo.12000

Supp, S. R. \& Ernest, S. K. M. (2014). Species-level and community-level responses to disturbance: a cross-community analysis. Ecology, 95(7), 1717-1723. doi: 10.1890/13-2250.1

Wilman, H., Belmaker, J., Simpson, J., Rosa, C., Rivadeneira, M. M. \& Jetz, W. (2014). EltonTraits 1.0: Species-level foraging attributes of the world's birds and mammals. Ecology, 95, 2027-2027. doi:10.1890/13-1917.1

\section{License: Creative Commons CC BY 4.0}

This article was published with open access for distribution under the terms of the Creative Commons Attribution License, which allows unrestricted use, distribution, and reproduction in any medium, provided the original work is properly cited. 